
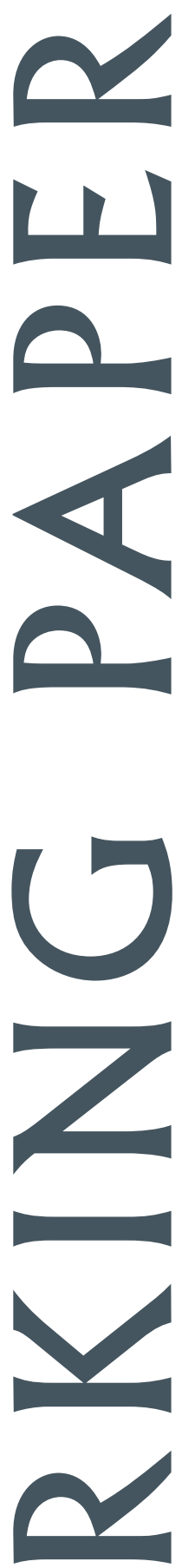

EAST-WEST CENTER 
The East-West Center is an education and research organization established by the U.S. Congress in 1960 to strengthen relations and understanding among the peoples and nations of Asia, the Pacific, and the United States. The Center contributes to a peaceful, prosperous, and just Asia Pacific community by serving as a vigorous hub for cooperative research, education, and dialogue on critical issues of common concern to the Asia Pacific region and the United States. Funding for the Center comes from the U.S. government, with additional support provided by private agencies, individuals, foundations, corporations, and the governments of the region.

East-West Center Working Papers are circulated for comment and to inform interested colleagues about work in progress at the Center.

For more information about the Center or to order publications, contact:

Publication Sales Office

East-West Center

1601 East-West Road

Honolulu, Hawai'i 96848-1601

Telephone: 808.944.7145

Facsimile: 808.944.7376

Email: ewcbooks@EastWestCenter.org

Website: www.EastWestCenter.org 


\section{Economics Series}

No. 94, February 2008

\section{Can Chinese IT Firms Develop Innovative Capabilities Within Global Knowledge Networks?}

\section{Dieter Ernst}

Dieter Ernst is a Senior Fellow at the East-West Center. Dr. Ernst was senior advisor to the OECD, Paris; research director at the Berkeley Roundtable, University of California/Berkeley; and professor of international business at the Copenhagen Business School. He has co-chaired an advisory committee of the U.S. Social Science Research Council on Innovation, Business Institutions, and Governance in Asia. He has served as scientific advisor to the Organization of Economic Cooperation and Development, the World Bank, the U.N. Conference on Trade and Development, and the U.N. Industrial Development Organization. His research covers global production and innovation networks and implications for industrial and technology policies. Books include Technological Capabilities and Export Success in Asia, What are the Limits to the Korean Model?, International Production Networks in Asia, and Innovation Offshoring - Asia's Emerging Role in Global Innovation Networks.

A revised version will be published in: China's Quest for Independent Innovation (Marguerite Gong Hancock, Henry S. Rowen, and William F. Miller, editors), Shorenstein Asia Pacific Research Center and Brookings Institution Press, 2008.

East-West Center Working Papers: Economics Series is an unreviewed and unedited prepublication series reporting on research in progress. The views expressed are those of the author and not necessarily those of the Center. Please direct orders and requests to the East-West Center's Publication Sales Office. The price for Working Papers is $\$ 3.00$ each plus shipping and handling. 


\title{
Can Chinese IT Firms Develop Innovative Capabilities Within Global Knowledge Networks?
}

\author{
Dieter Ernst, \\ East-West Center, Honolulu, Hawaii \\ ernstd@EastWestCenter.org
}

a revised version will be published in: "China's Quest for Independent Innovation" (Marguerite Gong Hancock, Henry S. Rowen, and William F. Miller, editors), Shorenstein Asia Pacific Research Center and Brookings Institution Press, 2008

\section{Introduction $^{1}$}

China's opportunities to build innovative capabilities in the IT industry differ from those faced earlier by Japan and East Asian NIEs. It has a unique combination of advantages in a booming market for electronics products and services; the world's largest pool of low-cost and easily trainable knowledge workers ${ }^{2}$; the emergence of sophisticated lead users and test-bed markets; and policy efforts to strengthen China's innovation system. As a late-late comer, it can learn from the achievements and mistakes of earlier latecomers.

The international environment is also dramatically different. Most important is the expansion of global knowledge networks. They have extended beyond markets for goods and finance into markets for technology and knowledge workers (Ernst, 2006a).

This raises two questions that are at the center of this chapter: Does integration into global knowledge networks facilitate the efforts of Chinese IT firms to develop innovative capabilities? If yes, precisely what type of capabilities are they developing?

The findings of this chapter can be summarized as follows:

- Integration into global knowledge networks exposes Chinese IT firms to leading-edge technology, "best-practice” management and sources of knowledge.

- Knowledge about its own markets and production sites helps them to exploit these opportunities. 
- Successful Chinese firms have not attempted to compete head-on with global leaders through radical innovations. Instead, they have focused on incremental and architectural innovations that support technology diversification strategies.

- Integration into global networks needs to be supported by a strong domestic innovation system.

These findings contradict a pessimistic literature that appraises China's innovative capabilities as weak. ${ }^{3}$ They also contradict fears, sometimes played up for political purposes, that Chinese firms could make radical innovations that would challenge U.S. technology leadership. ${ }^{4}$ A central proposition here is that Chinese IT firms make most progress in areas that escape the attention of both pessimists and proponents of an emerging technology threat.

\section{China's Integration into Global Knowledge Networks}

China is far more integrated into global knowledge networks than were Japan and Korea at a similar stage of their development. Formal corporate networks link Chinese firms to global customers, investors, technology suppliers and strategic partners through foreign direct investment (FDI) as well as through venture capital, private equity investment and contract-based alliances. And informal global social networks link China to more developed overseas innovation systems, primarily in the US, through the international circulation of students and knowledge workers.

\section{The Role of Foreign Direct Investment}

Since 2003, China has become the world's largest recipient of FDI, overtaking the US. FDI is nowhere more important than in high technology exporting. In 2005, foreigninvested enterprises (FIEs) produced 58\% of China's total exports, but $88 \%$ of hightechnology exports. And Taiwan-owned FIEs produced $60 \%$ of China's exports of computers and handsets.

In addition, practically all global IT industry leaders have begun to do R\&D in China (Ernst, 2006a). By 2004, China had become the third most important offshore R\&D location after the United States and the United Kingdom, followed by India (sixth) 
and Singapore (ninth) (UNCTAD 2005). ${ }^{5}$ Much of the R\&D offshoring to Asia is concentrated in the electronics industry, with China dominating R\&D for hardware.

As for non-equity forms of R\&D internationalization ("offshore outsourcing”), China is now the third most important location behind the United States and the United Kingdom and ahead of Germany and France. The same survey projects that China will be a more attractive location for future foreign R\&D than even the United States.

\section{Venture Capital and Private Equity Investment}

More recently, venture capital and private equity investment have added an important dimension to China's integration into corporate networks ${ }^{6}$. Venture capitalists in Silicon Valley now often require start-ups to present an "offshore outsourcing” plan as a condition for funding. This model keeps strategic management functions like customer relations and marketing, finance, and business development in Silicon Valley, while moving product development and research work to offshore locations (Ernst, 2006a).

An example is a start-up company in Beijing that specializes in mixed-signal chip design (Ernst, 2005a). Chinese engineers with PhD degrees from leading U.S. universities and who have worked as senior project managers in U.S. semiconductor companies founded the company. It has venture capital funding for developing chip designs in both China and Silicon Valley. A fully integrated design team in Beijing develops decoder chips customized for the new Chinese AVS (audio-video signal) standard. Of the more than 60 engineers in Beijing, 90 percent hold at least Masters Degrees. Five senior managers based in Santa Clara handle customer relations and provide design building blocks (the co-called SIPs) and tool vendors for design automation, testing and verification.

Private equity funding has also rapidly increased. Much of it takes place behind the scenes, and is difficult to document. ${ }^{7}$ A recent survey estimates that $\$ 1,300$ billion has been invested in global private equity, a figure set to rise significantly. ${ }^{8}$

One of these firms, the Texas Pacific Group (TPG), established a strong presence in Asia through its Hong Kong-based Newbridge affiliate, well ahead of other leading players. As discussed below, TPG has played a key role in Lenovo's acquisition of IBM's PC division.

\section{Informal Social Networks}


Equally important is China's integration into informal networks through the international circulation of students and knowledge workers. It has become intricately linked to overseas innovation systems through a massive brain drain of its students and, more recently, through a reverse brain drain that brings returnees and overseas knowledge workers home.

In 2005, China had more than 61,000 students in American universities, more than any other country except India. ${ }^{9}$ Associations of US-based Chinese engineers and managers such as Mount Jade, CASPA and NACSA channel information back and forth. China is also involved in US-centered professional peer group networks including IEEE and its many specialized working groups. China's large diaspora of skilled migrants helps to diffuse complex and often tacit knowledge about technology and management. Equally important are "IT mercenaries" from Taiwan, Hong Kong, Singapore, Malaysia and the Philippines, and more recently also from Japan, the US and Europe. These informal social networks provide much needed experience and links with markets and financial institutions, and can become an important source of reverse brain drain.

\section{Defining Innovative Capabilities}

An important challenge is to define this concept in a way that reflects globalizing markets for technology and knowledge workers and the resultant changes in the international innovation system (Ernst, 2002, 2005b, 2005c and forthcoming). Unfortunately, much of the literature on Asian innovation systems is based on empirical evidence that predates these transformations. ${ }^{10}$

However, it does provide important insights. It demonstrates, for instance, that distinctive economic structures and institutions offer quite different possibilities for learning and innovation, and hence should affect the design of innovation strategies.

Specifically, the economic structure (of a country, an industry and a region) affects a firm's specialization (i.e., its product mix), its learning needs as well as the breadth and depth of its capabilities while institutions shape how things are done and how learning takes place. An important concern is the "congruence" (Freeman, 1997:13) of different innovation subsystems, which is necessary to create a virtuous cycle of innovation.

\section{International Knowledge Sourcing}


Through integration into global production networks (GPNs), Asian firms have tapped into the world's leading markets, especially in the United States, and compensated for the initially small size of their domestic markets (Ernst, 1997; Borrus, Ernst, Haggard, 2000). It also has provided access to leading-edge technology and best-practice management approaches. This, in turn, has created new opportunities, pressures, and incentives for Asian network suppliers to upgrade their technical and management capabilities and worker skills (Ernst and Kim, 2002).

Asian economies (even the most successful ones), are constrained by weak domestic research capabilities and a narrow portfolio of home-grown intellectual property (Ernst, 2002). Hence, they need ways to attract R\&D by global firms. In a case study of Malaysia's electronics industry, Ernst (2004) demonstrates that attracting foreign R\&D not only compensates for initial knowledge weaknesses. It also helps their adaptation to abrupt changes in technology and markets. The study concludes that, under certain conditions, attracting R\&D by global firms may catalyze the development and the diffusion of innovative capabilities ahead of what the market would provide.

\section{Foreign R\&D Labs}

In considering the roles of foreign R\&D labs, it is important to distinguish between "home-base-exploiting" and "home-base-augmenting” ones (Kuemmerle, 1996). "Homebase-exploiting” overseas R\&D has been around for a long time. It adapts technology from the company's home base for commercialization overseas. In contrast, "home-baseaugmenting” overseas R\&D in Asia has become considerably more important since the 1990s. It taps into new knowledge from abroad and transfer it back home base (Kuemmerle 1997: 66) and combines diverse technologies in new products and processes (e.g., Granstrand, Patel and Pavitt, 1997).

The following taxonomy (Ernst, forthcoming) helps understanding of this topic. "Satellite" R\&D labs, the least developed type, combine elements of "home-baseexploiting” and "home-base-augmenting” R\&D. They are of relatively low strategic importance. "Contract" R\&D labs are the pure-play version of "innovation offshore outsourcing." For them, China's role is to supply lower-cost skills and infrastructure. Dense information flows link these labs with R\&D teams at headquarters and other 
affiliates and knowledge exchange is tightly controlled, and highly unequal. The highest stage, “(more) equal partnership” labs, is reserved for R\&D labs of global firms charged

with a regional or global product mandate. For them, barriers to knowledge exchange are supposed to be much lower, and may eventually give way to full-fledged mutual knowledge exchange.

Although satellite and contract R\&D labs continue to dominate (e.g., von Zedwitz, 2004; Gassmann and Han, 2004; Li and Zhong, 2003) there are examples of (more) equal partnerships, especially for the development of China's alternative standards in mobile telecommunications, open source software, and digital consumer electronics (Ernst and Naughton, 2005; Garcia and Burns, 2006).

Governments are playing key roles as promoters and funders of innovative capabilities. It shows that integration into global corporate knowledge networks increases the need for strong national innovation systems (Ernst, forthcoming).

\section{A Broad Definition of "Innovative Capabilities”}

I suggest using a broad definition, including not only technology knowledge but also complementary “soft” entrepreneurial and management innovations. Especially useful here is work on measures of firm-level innovations (Lall,1992; Ernst and O’Connor, 1992; Rasiah, 1995; Bell and Pavitt, 1995; Hobday, 1995; and Ernst, Ganiatsos, Mytelka, 1998). The last of these developed the first comprehensive taxonomy of firm-level capabilities required for production, investment, minor change, strategic marketing, establishing inter-firm linkages, and major changes. Its emphasis on strategic marketing is supported by recent case studies of Lenovo and China's handset industry (Xie and White, 2004 and 2005) that highlight the roles of distribution channels and close interaction with end users as preconditions for developing innovative capabilities. Ariffin (2000) documents the role of minor change capabilities and inter-firm linkages, while the importance of major change capabilities is emphasized by Amsden and Tschang (2003), who classified R\&D by technological complexity.

Here, I define “innovative capabilities” broadly to include the skills, knowledge and management techniques needed to create, change, improve and commercialize successfully products, services, equipment, processes and business models (Ernst, 
forthcoming). R\&D is important but so are complementary "soft" capabilities. Research on successful innovations demonstrates that "the technology is the easy part to change. The difficult aspects are social, organizational, and cultural" (Norman, 1998). In short, in addition to R\&D, I emphasize the following complementary "soft” innovative capabilities:

- sense and respond to market trends before others take note ("entrepreneurship")

- recruit and retain educated and experienced knowledge workers who are the carriers of new ideas

- global knowledge sourcing for core components, reference designs, tools, inventions and discoveries

- raise money required to bring an idea quickly to the market (the litmus test of innovation)

- deliver unique and user-friendly industrial designs (especially for fashion-intensive consumer devices, like mobile handsets)

- develop and adjust process management (methodologies, organization and routines) in order to improve efficiency and time-to-market

- manage knowledge exchange within multidisciplinary and cross-cultural innovation projects;

- participate in and shape global standard-setting;

- combine protection and development of intellectual property rights; and

- develop credible and sustainable branding strategies.

\section{Lenovo - Leveraging Linkages with Global Industry Leaders}

Lenovo shows how integration into global knowledge networks can influence the evolution of a company's business model and its development of innovative capabilities. This is exposing Lenovo to best-practice management approaches, intellectual tools and leading-edge technologies. Its recent expansion into global markets has culminated in it buying IBM's PC division, opening the door for private equity investors. Implementing this new business model poses major challenges but also provides new opportunities for learning. As long as its focus was on the China market, informal social knowledge 
networks remained China-centered but "going global” has considerably increased the pressure to globalize them.

\section{Ownership}

Lenovo is a "state-owned, privately-run" company whose state oversight virtually disappeared since being listed on the Hong Kong Stock Exchange in $1994 .{ }^{11}$ In 2003, the name Lenovo was chosen as one that could be used without restrictions in global markets.

The Lenovo Group Ltd. is part of the Hong Kong-listed conglomerate Legend Holdings Ltd., together with Digital China Holdings Ltd., which focuses on distribution and services, and Legend Capital, one of China’s leading corporate venture capital investors.

Liu Chuanzhi, the company's founder, was influenced by the experience of his father who, after working at the Bank of China had become a lawyer and moved to Hong Kong to become a specialist in intellectual property law. In 1984, he found himself stuck in a low-paid computer scientist position and was frustrated that the institute's research was not turned into something practical. His main motivation in founding the company was to commercialize ICT research.

When Legend was founded in 1984, all the ingredients for creating a successful start-up company were missing, and there were no established role models for doing this. This meant starting small, trading in whatever could be sold. Rather than proceeding from manufacturing to sales and then to $\mathrm{R} \& \mathrm{D}$, the company had to start as a trading company, a sequence typical of Hong Kong traders. It focused attention on peculiar features of the China market. After the mid-1980s, the China market expanded rapidly and by 2005 it was still growing seven times faster than the US one. And despite the entry of Dell and HP, Lenovo has remained the market leader for eight consecutive years, with about onethird of China’s market in 2005.

Lenovo owes its success to having user-friendly products and services, being less over-engineered and less expensive than those provided by global market leaders with features that address peculiar needs of China's markets. Its business model combines:

- familiarity with specific market characteristics and user requirements; 
- a superior domestic distribution network and information management;

- advanced industrial designs;

- strong brand recognition;

- reliance on a low cost structure; and

- access to well-educated and trainable knowledge workers.

\section{Learning From Global Market Leaders}

Much of Lenovo's success came through linkages with global market leaders. It entered the China market as a distributor of foreign products rather than as a manufacturer. ${ }^{12}$ In 1985, the company began to distribute computers by HP, IBM and AST. Especially from HP, Lenovo learned the basics of modern business management: "Legend learned to be more sensitive to the market and to market trends, and it learned the value of working with established procedures (Feng and Elfring, 2004:37). ”

Lenovo's current chairman, Yang Yuanqing, learned much from his close association with HP including formal decision-making procedures, the transition from a functional organization to business units, and the use of performance evaluation and incentives. Generous share options were used to recruit top university graduates and to poach aggressive young Chinese executives from leading global corporations. But the most important lesson was establishing a superior distribution network and the early introduction of an efficient, IT control system for inventory and accounts receivables.

Another important source of knowledge was contact with Taiwan's IT industry including brain-storming discussions at Acer and other leading Taiwanese PC companies that convinced the company to focus on the China market. In contrast to Taiwan, where a small market has forced companies to embark on global subcontracting, the China market was big enough to sustain a brand. It was hoped that the experience gained in China could be used to develop a brand internationally.

Since 2000, Legend has talked to a group of private equity investors at General Atlantic, originally looking for advice on how to spin-off Legend's distribution and software activities. This resulted in the 2001 listing of Digital China on the Hong Kong Stock Exchange (Primack, 2006). The chairman of General Atlantic, Steven A. Denning also serves on the Advisory Board of the School of Economics and Management at 
Tsinghua University and this apparently helped to establish contact with Liu Chuanzhi who as chairman of Legend Holdings, retains control behind the scenes.

For Lenovo's founder generation, education and work experience was overwhelmingly China-centered. Among the eight most senior Chinese executives of today’s Lenovo group, only one, Mary Ma (Senior Vice President and CFO), had studied abroad and had been in charge of international relations at the Chines Academy of Sciences (CAS). Another strength of Lenovo comes from its origin as a CAS-spin-off; its senior managers have retained strong ties to the academic research community. The new generation of managers has been much more exposed to international networks through overseas graduate studies, travel and work (Interview Beijing 0526 06).

\section{Developing Innovative Capabilities}

Over time, Legend developed close relations with a set of technology suppliers. In addition to IBM and HP, this included Intel, Microsoft, Hitachi, Siemens, and Texas Instruments. It decided to use only the best of Intel's microprocessors and Intel selected it as its first strategic partner in China. As a result, most of the company’s executives have participated in Intel's organizational training programs.

Another strength is in industrial design and materials. Legend's success in the China market owed much to its decision in 1998 to introduce a laptop (the Tianxi model) for consumers and small businesses, melding a stylish design with performance features that suited this market. ${ }^{13}$ It was introduced after two years of work that involved some of the leading global players in materials, such as GE Plastics and Nike, and well-known design firms such as Palo Alto-based IDEO and Portland-based Ziba Design.

\section{Going Global}

Around 2004, the company realized that it had to expand beyond its China base if it wanted to avoid a slow-down. Its domestic market leadership was under attack from Dell and HP, who benefited from support by Taiwanese contract manufacturing partners. This exposed two fundamental weaknesses: 
- A heavy reliance on China's price-sensitive and low-margin markets. Together with insufficient size and limited economies of scale and scope this could squeeze the company's profits.

- The limited funds available for developing new products and services and developing global brand recognition.

With revenues of HK\$ 22 billion (roughly US\$ 2.9 billion) in 2005, the company was much smaller than global industry leaders. A telling indicator of the company's lack of exposure to global markets was that, as of the end March 2005, only 57 of its 9,682 employees were employed outside mainland China (mostly in Hong Kong).

Lenovo's response was to develop a distinct global brand and to expand its global market share. ${ }^{14}$ The strategy focused on what it saw as the weak spot of global market leaders and their Taiwanese partners by offering less over-engineered and expensive products than theirs with performance features that reflect specific characteristics of the target markets. ${ }^{15}$ This required gaining insights in how to penetrate the extremely demanding lead markets (especially the US).

\section{Acquiring IBM's PC Division}

In December 2004, Lenovo bought IBM’s PC division - a move that shook the industry. This take-over of an American icon, albeit a highly unprofitable part of Big Blue, provides "the best laboratory in which to study a blended Chinese and Western management model (McGregor, 2005: 289).

Private equity investors were instrumental in bringing about this deal, the IBM PC acquisition, by providing information and helping Lenovo navigate stormy US political waters. According to one source,

"Liu (Chuanzhi) called General Atlantic, and asked for help determining if such an acquisition would make sense. If Lenovo were to bid and win, Liu told GA, the private equity firm would be welcomed in as an equity participant on the deal. GA agreed, conducted due diligence, and told Liu that the acquisition would, indeed, make sense.”(Primack, 2006)

Lenovo paid US\$1.25 billion for IBM’s PC division and assumed debt, which brought the total cost to US\$1.75 billion. Initially, IBM was reported to gain an 18.9 
percent stake in Lenovo, but this soon changed. As part of its acquisition of IBM, Lenovo received a US\$350 million private equity commitment from Texas Pacific Group (US\$200 million), General Atlantic (US\$100 million) and Newbridge, TPG’s Asian affiliate (\$50 million). The entry of these new investors will shrink IBM’s eventual share in Lenovo to $13.4 \%$, down from the 18.9\% first reported (China IT Weekly, 1 April 2006). Upon full conversion of preferred shares and after share issuance to IBM, the private equity investors are expected to hold around 12.4\% of Lenovo’s capital.

As a result, private equity investors are now involved "in much of the decisionmaking... (and)... are treated as partners instead of like minority investors” (Primack, 2006). It is too early to judge how this will affect the long-term development of Lenovo’s innovative capabilities.

\section{Implementation Challenges}

The challenges of implementing this acquisition are huge: to compete in a business with slim margins and fierce competition while patching together complicated supply chains, sales networks and information systems. The new Lenovo needs to retain IBM Think Pad customers, while developing its own brand.

An equally important challenge is keeping cost leadership. The new company has four times the revenue of the old Lenovo, but six times the staff cost of the China group alone and only twice the profit. With one stroke, Lenovo’s workforce more than doubled, from around 9,000 to almost 21,000. Of those 10,000 originally from IBM, 40\% were then in China and 25\% in the U.S. It did not take long for management to respond. The company soon announced staff layoffs, most of them ex-IBM employees outside China.

Another challenge is bringing together two vastly different work forces, in terms of demographics and behavior. The average age of Lenovo employees is 27.5 years. Many senior Lenovo managers are promoted within a few years; some even got three promotions within a year while IBM executives are older and more experienced. In addition, IBMers are used to a management style that is highly structured (some would say “bureaucratic”) and may not be easily reconciled to Lenovo’s peculiar blend of authoritarian top-down decision-making and Silicon valley-type remuneration packages for US-based employees. 
A clash seemed unavoidable. The first CEO of the new Lenovo, an IBM veteran, left after only a few months. The new one, William J. Amelio was hired by TPG. He had worked in IBM's PC division from 1979 to 1995 but arguably his greatest attraction for Lenovo was his position with Dell since 2001 where, as Senior Vice President for AsiaPacific and Japan, he had shaped Dell’s aggressive market penetration strategies.

\section{Opportunities}

However, this diversity of management cultures could also become a source of learning. For instance, only 18\% of Lenovo’s pre-acquisition revenues came from laptops, while that share for IBM's PC division was 60\%. For IBM, corporate customers represented almost $60 \%$ of revenues while $83 \%$ of Lenovo's revenues came from small businesses and consumers. Most importantly, Lenovo expected to benefit from IBM's global presence to overcome its lack of experience in overseas markets.

A greater exposure to global networks starts with the top executives. Seven out of the 15 most senior executives of Lenovo now are non-Chinese, two educated in India, one in Canada and one (of Greek origin) in Australia. Of particular importance is their work experience. For instance, Ravi Marwaha, Senior Vice President for Geographies, has worked in India and Australia. Bill Matson who, as Senior Vice President for Human Resources, bears responsibility for blending the merged company's diverse labor forces, has 24 years of experience with IBM in global human resources management.

Lenovo expects to gain access to a worldwide network of skilled computer sales and distribution employees who know tax laws and invoicing practices in 66 countries. The same is true for R\&D. After the acquisition, Lenovo's R\&D workforce went from 1,100 to 1,800 . This represents about $9.5 \%$ of Lenovo’s total workforce, and about $18 \%$ of its non-manufacturing workforce.

Noteworthy is the addition of two IBM R\&D labs, in Yamato/Japan and North Carolina. Before the acquisition, Lenovo’s R\&D was almost completely China-centered, with main centers in Beijing, Shanghai and Shenzhen.

Yamato is credited with developing IBM's highly rated ThinkPad family of laptops and Lenovo will use this experience on notebook development in addition to its work on RFID (radio frequency identification) technology. In North Carolina, Lenovo 
decided to invest US\$84m in a new R\&D campus that will house more than 2,200

employees. This will increase Lenovo's North Carolina headcount by around $400 .^{16}$ It will focus on desktop computers, software, product definition and quality control.

An important part of the takeover agreement is that Lenovo can use the IBM brand for five years, including the successful “Think” brand. IBM has promised to support Lenovo with marketing and with its IBM corporate sales force.

In addition, Lenovo can now add around 1,500 IBM patents to its own 1,000 patents. As most of the former IBM patents are registered at the USPTO, this could help Lenovo to overcome its almost exclusive reliance on patenting in China, and to gradually internationalize its patent portfolio. ${ }^{17}$

Immediate benefits include technical support from IBM R\&D labs, access to global market intelligence and distribution know-how, and learning for further development of Think Pad laptops. The acquisition of 1,500 IBM patents might also generate additional income for Lenovo It is an open question, however, to what degree this will enable Lenovo to strengthen and upgrade its own innovative capabilities.

\section{Assessment of Innovative Capabilities}

What specific innovative capabilities have been developed by Lenovo and other Chinese IT companies? To address this question, I distinguish among incremental, modular, architectural and radical innovations (Henderson and Clark,1990). I use this taxonomy to examine why the more successful Chinese IT firms tend to focus on a combination of incremental and architectural innovations, modular innovations are less frequent, and radical innovations are limited to state-supported mega-projects.

\section{“Incremental” Innovations}

"Incremental” innovations take both the dominant components and architecture for granted, but improve on cost, time-to-market and performance. They do not require science inputs but do require skill and ingenuity, especially in what I called earlier complementary 'soft' entrepreneurial and management capabilities.

Examples are improvements in the organization of manufacturing, distribution and support services, like Dell’s “direct sales” model and its integration of factory 
automation and supply chain management. Other examples are new ways of subcontracting, pioneered by Taiwanese IT firms, like original design manufacturing (ODM), foundry services (for integrated circuit fabrication), and design implementation services (Ernst, 2006b). They can also involve continuous improvements in industrial design.

Chinese IT firms are well placed to pursue "incremental" innovations across all stages of the value chain. They operate in extremely price-sensitive markets, especially in China, but also as suppliers to global industry leaders. Hence, they are under tremendous pressure to improve on cost, time-to-market and performance. These normally can be achieved through relatively minor changes to the existing product or production process.

Barriers to such improvements are relatively low, as tools and methodologies are familiar and investments tend to be low and predictable. Most importantly, they build on existing operational and engineering skills as well as the management of supply chains, customer relations and information systems.

An example is the set of easy-to-use "Lenovo Care" support tools in the company's 3000 series desktops and laptops that provide automatic updates and offer one-button system recovery. Drawing on IBM's ThinkVantage technology, Lenovo has improved these tools with the result that the J-series has gotten reviews as a smart, versatile and affordable choice for small businesses—one of the few market segments in the PC industry that display reasonable growth.

\section{“Modular” Innovations}

"Modular" innovations introduce new component technology and plug it into a fundamentally unchanged system architecture. This type has been a defining characteristic of the PC industry - within each generation of the Wintel architecture (combining Microsoft's Windows operating system and Intel's microprocessors), specialized suppliers have introduced new component technology, for instance for memory, storage and display devices (e.g., Langlois and Robertson, 1992; Baldwin and Clark, 2000). These have been made possible by a division of labor in product development: "(m)odularity is a particular design structure, in which parameters and tasks are interdependent within units (modules) and independent across them.” (Baldwin 
and Clark, 2000: 88). One consequence has been the disintegration of the innovation value chain as well as its dispersion it across firm boundaries and geographic borders, giving rise to "innovation offshoring” through global innovation networks (Ernst, 2006a).

Although modularity has created opportunities for industrial latecomers the barriers to it are substantial. High technological complexity requires top scientists and experienced engineers in different fields. In addition, investment requirements can be very substantial (around US\$3 billion for a state-of-the-art semiconductor fabrication plant), as are risks of failure.

This probably explains why it is difficult to find "modular" innovations by Chinese IT firms. Huawei provides a few examples of projects to develop new component technology that can be plugged into unchanged system architecture. It has substantially strengthened its capabilities in software development, with its R\&D lab in Bangalore playing an important role. ${ }^{18}$ Huawei has also invested heavily in the development of ASIC chips, embedded software and shared platforms for communication and networking equipment (Ernst, 2006c). Until recently, its internal semiconductor design unit supplied no more than $10 \%$ of the chips the company needs, a share that is now expected to increase substantially. After the company had spun-off its independent chip design company Hi-Silicon, Huawei reported the completion of design projects for nearly 100 types of ASIC chips, including so-called IP cores for 3G mobile systems.

For Lenovo, an innovation that relies on the introduction of new materials is the 'roll-cage' technology developed by the company for its Thinkpad Z series laptops. This technology provides extra physical protection, by fusing a magnesium alloy skeleton into the chassis of the laptop. Coupled with the existing titanium exterior, the laptops are supposed to better survive falls, bumps, and other shocks.

\section{“Architectural” Innovations}

"Architectural" innovations are "innovations that change the architecture of a product without changing its components" (Henderson and Clark, 1990: 9). They use existing component technologies but change the way they work together.

What enables industrial latecomers to pursue "architectural" innovations? By definition, latecomers like Chinese IT firms, continue to lag behind industry leaders in 
the breadth and depth of their innovative capabilities. Their strength however is their familiarity with China's markets and institutions and exposure to user requirements that global industry leaders have neglected. Chinese firms might be able to use this knowledge to penetrate its large mass markets. Doing this requires a change in the architecture of a product or service but not new components. They can buy these components from specialized suppliers.

An early example is the development of China's electronic switching system HJD04; the innovation is a system architecture that optimizes the specific features of the national telecommunications network to match specific needs of the service providers (Shen, 1999). Other examples are the development of Chinese-language electronics publishing systems by the Founder Group Company (Lu, 2000: chapter 4), the development of the unique Chinese video compact disk (VCD) technology, and the successful transition to Chinese DVD system technology (Lu Fang and Ling Mu, 2003).

Two recent examples of new features being added to existing architectures are Lenovo's Tianxi laptop and Huawei’s development of a new integrated IP service platform, ME 60.

\section{Tianxi laptop (Lenovo)}

Lenovo's Tianxi laptop computer is tailored for private consumers and small businesses in China. Global firms were uninterested, and for apparently good reasons; in the mid-1990s, an ordinary PC cost RMB 13,000, the equivalent of one or two year's salary for an ordinary family (Feng and Elfring, 2004: 61).

Legend started by developing a home computer for the Chinese family. The cheapest model, priced at RMB 3,000, did not even have a hard disk. Through trial-anderror the company found what Chinese consumers wanted. Using Intel's new Pentium processors, while global companies still shipped PCs with the older 486 processors to China, Lenovo provided user-friendly features through in-house design of ASICs (=application-specific integrated circuits) and add-on cards.

The Tianxi project aimed to provide Internet access at an affordable price within an attractively designed box. A defining characteristic was its "one-touch-to-the Net" button that enabled national roaming. Through an arrangement with China Telecom, the 
Internet registration process was dramatically simplified, which meant that users no longer had to go to the PTT for an account-a process that was famously complicated. Buyers of the Tianxi received a year of free Internet access and a special pen allowed Tianxi users to write Chinese-character emails.

\section{Huawei's Integrated IP Service Platform ME 60}

Current IP networks do not offer the security and quality of service that operators want, while traditional networks are incapable of supporting bandwidth-hungry multimedia services such as IPTV. Such products need to be aggregated and run over a common IP core. ${ }^{19}$ The ME60 is the "Swiss army knife" that does this. Technically, this system is quite an achievement. As a 10-Gigabit multi-service control gateway, ${ }^{20}$ the $\mathrm{ME}$ is an edge router that sits between the IP core and the access network (which may be fixed or mobile). It can deliver tailor made products in response to customers' specific needs. Such integrated solutions are not widely offered in the network equipment industry where incumbent industry leaders typically provide standard solutions. In addition, many of their products provide leading edge technology that exceeds by far the needs of most users. These high $R \& D$ costs necessitate a business model that seeks to reap economies of scale through "mass-manufacturing” of standard and fairly inflexible solutions.

\section{“Radical” Innovations}

Finally, “radical” innovations involve both new component technology and changes in architectural design. They require breakthroughs in both architectural and component knowledge. Examples include the discovery of new drugs, or the invention of the Internet. In China, an interesting example is the development of the "pebble bed" reactor that offers the hope of cheap and safe nuclear power stations ("China in Drive for Nuclear Reactors”, Financial Times, 8 February 2005: 4).

Radical innovations require dense interaction with leading-edge science and require a broad base of capabilities in a society-top scientists and engineers are needed who work at the frontier of basic and applied research in a broad range of disciplines. 
In short, such innovations are costly and risky, and failure can destroy even large, well-endowed companies. They are beyond the reach of most IT companies in China, with the possible exception of state-supported mega-projects for instance for military and space projects.

An example is Lenovo's super computers. The first project was the DeepComp 1800 supercomputer, introduced in 2001, which, based on 526 Intel Xeon processors, was ranked $51^{\text {st }}$ by 2002 by the Association for Computing Machinery (ACM). This was followed in 2003 by the DeepComp 6800 model that was ranked $14^{\text {th }}$ worldwide. The most recent one, the 1000 TFLOPS supercomputer, was started in 2005 and is scheduled for completion before 2010. It is supposed to be nearly ten times more powerful than the world's fastest supercomputer. The underlying rationale was clearly more political than commercial, as shown from the following quote: "China will need more supercomputing power in the years ahead to maintain its economic growth and development, China cannot rely on other countries to develop a supercomputer that meets its needs” (InfoWorld, 28 July 2005).

In short, for Chinese IT firms, "radical” innovations pose a difficult challengeinvestment requirements are huge and require substantial government support, while markets are likely to be small. There may however be indirect commercial benefits, as successful completion of a radical innovation project may help to establish a company as a serious player and foster its brand image.

\section{Technology Diversification}

In short, in addition to "incremental” innovations, a focus on "architectural” innovations makes more sense for Chinese firms than "modular” or "radical” innovations. An ability to profit from architectural innovation may seem counter-intuitive, but it follows from their knowledge of Chinese markets and their capacity to complement missing pieces through their integration into global networks. A combination of “incremental” and "architectural” innovations should enable Chinese IT companies to pursue a strategy of “technology diversification” (Ernst, 2005d). Defined as the expansion of a company's or a product's technology base into a broader range of technology areas (Granstrand, 1998), it focuses on applied research and the development 
of products that draw on component and process technologies that are not necessarily new to the world or difficult to acquire.

“Technology diversification” builds on strengths in distribution, supply chain management and manufacturing and can use experience in providing lower- cost integrated solutions to customers with limited resources and who require strong support services. Most importantly, it could enable them to leverage their participation in global networks.

\section{Conclusions}

Integration into global knowledge networks helps industrial latecomer societies like China by exposing them to best-practice management approaches, intellectual tools and sources of knowledge on leading-edge technology.

An important finding here is that successful companies have not attempted to jump into “technology leadership” roles, trying to compete head-on with global technology leaders through "radical” innovations. Instead, they have focused on "incremental" and "architectural" innovations that allow them to pursue "technology diversification” strategies.

This chapter does not address government policies. It is clear, however, that there is ample scope for policies to help the development of firm-level innovative capabilities (Ernst, 2005d and 2000). In fact, integration into global knowledge networks increases the need for a strong national innovation system. The needed policies are very different from earlier top-down "command economy"-type ones that were characteristic of the “East Asian development model.”

Such policies can only succeed if they fulfill two conditions: they need to balance protection of intellectual property rights with incentives for knowledge diffusion to local firms; and they need to provide a sufficiently large pool of people with the skills needed to benefit from integration into global knowledge networks. There are no quick fix solutions. Successful innovations require fundamental adjustments in institutions and behavior. They take time in any country, and even more so in China, because of the uncertainty and instability created by its recent transition to capitalism. 


\section{References}

Amsden A.H. and F.T. Tschang, 2003, “A New Approach to Assessing the Technological Complexity of Different Categories of R\&D (with examples from Singapore)”, Research Policy, April 2003, vol. 32, no. 4, pp. 553-572.

Arrifin, N, 2000, Internationalisation of Innovative Capabilities: The Malaysian Electronics Industry, PhD thesis, Science Policy research Unit, University of Sussex.

Baldwin, C.W. and K.B.Clark, 2000, Design Rules: The Power of Modularity, Cambridge, Mass: MIT Press.

Bell, M. and K. Pavitt, 1993, "Technological Accumulation and Industrial Growth: Contrasts Between Developed and Developing Countries", Industrial and Corporate Change, Vol. 2., pages 157-210.

Bell, M. and K. Pavitt, 1995, “The Development of Technological Capabilities”, in I. Ul Haque et al, eds, Trade, Technology and International Competitiveness, The World Bank, Washington, D.C., pp. 69-101.

Borrus, M., D. Ernst and S. Haggard, 2000, "Cross-Border Production Networks and the Industrial Integration of the Asia-Pacific Region”, in: Borrus, M., D. Ernst and S. Haggard (eds.), International Production Networks in Asia. Rivalry or Riches?, London: Routledge.

British Venture Capital Association, 2006, An Introduction to Private Equity, at http://www.bvca.co/publications (accessed 12 May 2006).

Ernst, D., 1997, From Partial To Systemic Globalization. International Production Networks In The Electronics Industry, report to Sloan Foundation, published as The Data Storage Industry Globalization Project Report 97-02, San Diego, California: Graduate School of International Relations and Pacific Studies, University of California at San Diego.

Ernst, D., 2002, “Global Production Networks And The Changing Geography Of Innovation Systems: Implications for Developing Countries,” Economics of Innovation and New Technologies, Vol. XI, No. 6

Ernst, D., 2004, “Global Production Networks in East Asia’s Electronics Industry and Upgrading Perspectives in Malaysia”, in: S. Yusuf, M.A. Altaf and K. Nabeshima (eds.), Global Production Networking and Technological Change in East Asia, a co-publication of the World Bank and Oxford University Press, Washington, D.C.

Ernst, D. 2005a, “Complexity And Internationalization Of Innovation: Why Is Chip Design Moving To Asia?” in International Journal of Innovation Management, special issue in honor of Keith Pavitt, Vol. 9, No. 1, pp. 47-73. 
Ernst, D., 2005b, “Limits To Modularity - Reflections On Recent Developments In Chip Design,” Industry and Innovation, Vol. 12, No.3: 303-335

Ernst, D., 2005c “The New Mobility Of Knowledge: Digital Information Systems And Global Flagship Networks,” in Latham, R. and Sassen, S. (eds.), Digital Formations: IT And New Architectures In The Global Realm, Princeton, New Jersey: Princeton University Press.

Ernst, D. 2005d, "Pathways To Innovation In Asia’s Leading Electronics-Exporting Countries - A Framework For Exploring Drivers And Policy Implications,” special issue, "Competitive Strategies of Asian High-Tech Firms, International Journal of Technology Management, Vol. 29, No. 1/2, pp. 6-20.

Ernst, D., 2006a, Innovation Offshoring: Asia's Emerging Role in Global Innovation Networks, a special report prepared for the East-West Center and the U.S.-Asia-Pacific Council, East-West Center, Honolulu, July.

Ernst, D., 2006 b, Developing Innovative Capabilities in Chip Design. Insights from the US and Greater China, manuscript, East-West Center, Honolulu

Ernst, D., 2006 c, “Building Innovative Capabilities within Global Knowledge Networks - the Case of Huawei”, manuscript, East-West Center, Honolulu.

Ernst, D., forthcoming, INNOVATION OFFSHORING - Asia's Emerging Role in Global Research and Development Networks, book manuscript, East-West Center, Honolulu.

Ernst, D., Ganiatsos T., and Mytelka, L. (eds.), 1998. Technological Capabilities And Export Success - Lessons From East Asia, London, United Kingdom: Routledge Press.

Ernst, D. and Kim, Linsu, 2002, “Global Production Networks, Knowledge Diffusion And Local Capability Formation,” Research Policy, Vol. 31, No. 8/9, pp. 1417-142

Ernst, D. and Naughton, B., 2007, China's Emerging Industrial Economy - Insights From The IT Industry, chapter 3 in: McNally Chris (ed), Capitalism in the Dragon's Lair, London, Routledge

Feng, S. and J. Elfring, 2004, The Legend Behind lenovo. The Chinese IT company that dares to succeed, Asia 2000, Hong Kong.

Freeman, C., 1987, Technology Policy and Economic Performance: Lessons from Japan, London: Pinter Publishres.

Freeman, C., 1997, "Innovation Systems: City-State, National, Continental and SubNational”, mimeo, Science Policy Research Unit (SPRU), University of Sussex, December. 
Garcia, D. L. and Burns, K., 2006, “Globalization, Developing Countries, And The Evolution Of International Communities of Standard Setting Practice,” paper prepared for China’s Technology Standards Policy Workshop, Tsinghua University, Beijing, China, January 6.

Gassmann, O. and Han, Zheng, 2004, "Motivations And Barriers Of Foreign R\&D Activities In China,” R\&D Management, Vol. 34, No. 4, pp. 423-437.

Gilboy, G.F., 2004, “The Myth Behind China’s Miracle”, Foreign Affairs, Jul/Aug;

Granstrand, O., 1998, “Towards A Theory Of The Technology-Based Firm,” Research Policy.

Granstrand, O., Patel, P., and Pavitt, K., 1997, "Multi-Technology Corporations: Why They Have 'Distributed' Rather Than 'Distinctive Core' Competencies,” California Management Review, Vol. 39, No. 4, pp. 8-25.

Henderson, R.M.. and K.B.Clark, 1990, “Architectural Innovation: The Reconfiguration of Existing Systems and the Failure of Established Firms", Administrative Science Quarterly, March, 9-30.

Hobday, M., 1995, Innovation in East Asia: The Challenge to Japan, Edward Elgar, Aldershot.

Kim, L., 1997, Imitation to Innovation: The Dynamics of Korea's Technological Learning, Boston: Harvard Business School Press.

Kuemmerle, W., 1996, Home Base And Foreign Direct Investment In R\&D, unpublished Ph.D. Dissertation, Boston, Massachusetts: Harvard Business School.

Kuemmerle, W., 1997, “Building Effective R\&D Capabilities Abroad,” Harvard Business Review, March-April, pp. 61- 70.

Kygne, James, 2006, China Shakes the World. The Rise of a Hungry Nation, Weidenfeld \& Nicolson, London

Lall, S., 1992, “Technological Capabilities and Industrialisation”, World Development, Vol. 20 \#2, pp.165-186

Lall, S., 2000, "Technological Change and Industrialization in the Asian Newly Industrializing Economies: Achievements and Challenges”, in: L. Kim and R.R. Nelson, eds, Technology, Learning and Innovation. Experiences of Newly Industrializing Economies, Cambridge: Cambridge University Press. 
Langlois, R.N. and P.L.Roberston, 1992, Networks and Innovation in a Modular System: Lessons from the Microcomputer and Stereo Component Industries”, Research Policy, 21: 297-313.

Li, Jiatao and Zhong, Jing, 2003, "Explaining The Growth Of International R\&D Alliances In China,” Managerial And Decision Economics, 24, pp. 101-115.

Ling, Zhijun, 2006, The Lenovo Affair. The Growth of China's Computer Giant and Its Takeover of IBM-PC, Singapore, John Wiley \&Sons (Asia)

Lu Fang and Ling Mu, 2003, “Indigenous Innovation, Capability Development and Competitive Advantage: The Origins and Development of the Competitiveness of Chinese VCD/DVD Industry", unpublished paper, presented at the Annual Meeting of the Business History Conference, University of Massachusetts at Lowell, Massachusetts.

Lu, Qiwen, 2000, China's Leap Into The Information Age: Innovation And Organization In The Computer Industry, Oxford, United Kingdom: Oxford University Press.

McGregor, J., 2005, One Billion Customers. Lessons from the Front Lines of Doing Business in China, New York etc: Free Press.

Nelson, R.R. and H. Pack, 1999, “The Asian Miracle and Modern Growth Theory”, The Economic Journal, 109, pp. 416-436

Nolan, P., 2001, China and the Global Business Revolution, London: Palgrave.

Norman, D.A., 1998, The Invisible Computer, Cambridge, Massachusetts: MIT Press.

Primack, D., 2006, Lenovo gives TPG, General Atlantic a China Presence, Buyouts, 6 March

Rasiah, R., 1995, Foreign Capital and Industrialization in Malaysia, Macmillan, Basingstoke

Rosen, D.H., 2003, “Low-tech bed, high-tech dreams”, China Economic Quarterly, Q4.

Shen, Xiaobai, 1999, The Chinese Road to High Technology. A Study of Telecommunications Switching Technology in the Economic Transition, New York: St. Martin’s Press.

Steinfeld, E.S., 2004, “Chinese Enterprise Development and the Challenge of Global Integration, in S. Yusuf, M.A. Altaf and K. Nabeshima (eds.), Global Production Networking and Technological Change in East Asia, a co-publication of the World Bank and Oxford University Press, Washington, D.C. 
UNCTAD, 2005, "UNCTAD Survey on the Internationalization of R\&D,” Occasional Note, December 12.

US -China Economic and Security Review Commission, congressional hearing held at Stanford in April 2005 on China's High Technology Development, at: http://www.uscc.gov/hearings/2005hearings/transcripts/05_04_21_22.pdf

Von Zedwitz, M., 2004, “Foreign R\&D Laboratories In China,” $R \& D$ Management, Vol. 34, No. 4.

Xie, W. and S. White, 2004, "Sequential Learning in a Chinese Spin-Off: The Case Of Lenovo Group Ltd”, R\&D Management, 34: 407-422.

Xie, W. and S. White, 2005, "Windows of Opportunity, Learning Strategies and the Rise of China’s handset Makers”, INSEAD Working Paper, Singapore.

\footnotetext{
${ }^{1}$ I gratefully acknowledge ideas, comments and suggestions from Henry Rowen, William Miller, Naushad Forbes, Greg Shea, Clark Duncan, Richard P. Suttmeier, Barry Naughton, Ron Wilson, Xielin Liu, Xudong Gao, Lan Xue, Chintay Shih, Kane Wang, T.C.Tu, Shin-Horng Chen, Pang Eng Fong, Wong Poh Kam, Eric Baark, Ted F. Tschang, Xiaobai Shen and Adam Segal. At the East-West Center, I am grateful to Charles Morrison and Nancy Lewis for supporting this research. The Volkswagen Foundation provided generous funding. Kitty Chiu, Peter Pawlicki and Rena Tomlinson provided excellent research assistance.

2 "Knowledge workers" are defined to include science and engineering personnel, as well as managers and specialized professionals (in areas like marketing, legal services and industrial design) that provide essential support services to research, development and engineering.

${ }^{3}$ For instance, Nolan, 2001; Steinfeld, 2004; Gilboy, 2004; Rosen, 2003.

${ }^{4}$ See, for instance, the congressional hearing of the US -China Economic and Security Review Commission, held at Stanford in April 2005 on China's High Technology Development, at: http://www.uscc.gov/hearings/2005hearings/transcripts/05_04_21_22.pdf

${ }^{5}$ The UNCTAD sample consists of the first 300 firms of the R\&D scoreboard of the 700 top worldwide R\&D spenders, published by the UK Department of Trade and Industry (DTI).

${ }^{6}$ Private equity investment is medium- to long-term finance provided in return for an equity stake in potentially high-growth companies that are not listed on a major public stock exchange. According to the British Venture Capital Association, it encompasses both "venture capital" (from the seed to the expansion stages of investment) and management buy-outs and buy-ins.

${ }^{7}$ Sources include the US and the UK National Venture Capital Associations and consulting firms like Greenwich Associates, Private Equity Intelligence (PEI) and Shanghai-based Zero2IPO for China.

${ }^{8}$ Courtesy of Private Equity Intelligence (PEI), a London-based specialized consulting firm (July 6, 2006)

${ }^{9}$ Data, courtesy of the U.S. Council of Graduate Schools, March 2006
} 
${ }^{10}$ Freeman, 1987, Bell and Pavitt, 1993; Kim Linsu, 1997; Nelson and Pack, 1999; Lall, 2000; Hobday, 1995; Ernst, Ganiatsos, Mytelka, 1998; Ernst and O’Connor, 1989 and 1992

${ }^{11}$ On the origins and evolution of the company see Lu (2000); Ling (2006); Feng and Elfring (2004); and Kynge (2006, chapter 7).

${ }^{12}$ This decision was imposed by the company's failure to secure a manufacturing license from the Ministry of Electronics Industry (MEI). Instead, licenses went to companies that were part of the "MEI family", like Great Wall which was then the largest domestic producer.

${ }_{14}^{13}$ Plastics News Report, 9 December 2005

${ }^{14}$ According to Lenovo Group chairman Yang Yuanqing, “(w)e will make money but we don’t focus on profit, we focus on growth", adding that this phase may last at least two years. (quoted in Network World, 9 December 2005)

${ }^{15}$ An example are Lenovo's first computers sold under its own brand outside China - the Lenovo $3000 \mathrm{~J}$ series Desktops and 3000 C Notebooks. These models target lower performance at a lower price for overseas markets.

${ }^{16}$ Lenovo is to benefit from a $\$ 750,000$ grant from the One North Carolina Fund, as well as up to $\$ 8.4 \mathrm{~m}$ in tax incentives from a Joint Development Investment Grant if it meets employment and performance targets. ${ }^{17}$ As of June 2004, Lenovo had registered 787 patents in China, entering for the first time the top ten lists of the most competitive intellectual property owners in China. But a search in the USPTO patent data base showed that, from 1976 to present, Lenovo had registered only 34 patents.

${ }^{18}$ According to China's Ministry of Information Industry (MII), Huawei is now one of the three largest domestic Chinese software enterprises (together with ZTE and Haier).

${ }^{19}$ The IP core, also sometimes called backbone, is the primary path of an IP network traffic. It connects smaller segments of a network and has a high concentration of traffic.

${ }^{20}$ A gateway is the entrance to another network. The gateway allows equipment with different protocols to communicate. 